\title{
Tracking Immigrant Professionals' Experience in Manitoba's Labour Market
}

Stephanie Stobbe and Judith Harris RCIS Working Paper No. 2013/6 October 2013

SERIES EDITOR

Harald Bauder

Ryerson Centre for Immigration \& Settlement Ryerson University Jorgenson Hall, 620 350 Victoria Street, Toronto, ON M5B2K3 http://www.ryerson.ca/rcis 


\title{
RCIS Working Paper
}

No. $2013 / 6$

\section{Tracking Immigrant Professionals' Experience in Manitoba's Labour Market}

\author{
Stephanie Stobbe and Judith Harris \\ University of Winnipeg
}

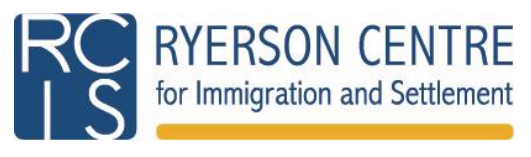

Series Editor: Harald Bauder

RCIS Working Papers present scholarly research of all disciplines on issues related to immigration and settlement. The purpose is to stimulate discussion and collect feedback. The views expressed by the author(s) do not necessarily reflect those of $\mathrm{RCIS}$. For a complete list of RCIS publications, visit www.ryerson.ca/rcis

ISSN: 1929-9915

This RCIS Working Paper was presented at the 2013 RCIS conference "Immigration and Settlement: Precarious Futures?" held at Ryerson University, May 15-17, 2013. This publication and the conference received funding from the Social Sciences and Humanities Research Council of Canada. 


\begin{abstract}
Our project aims to improve immigrant integration programs by exploring the immigration and settlement process from the perspective of professionals and trades people who are clients of Winnipeg's Success Skills Centre, an agency that offers employment assistance services to immigrant professionals and skilled workers. We make three observations on the integration experience of immigrant professionals and trades people in the Manitoba labour market. First, recent immigrants to Manitoba through the Provincial Nominee Program (PNP) have been educated and skilled, yet their labour market participation has often been restricted to general labour and entry-level employment. Second, immigration policy sets a minimum amount of money that an adult immigrant has to bring with him or her, resulting in a demand/supply mismatch in the labour market. Finally, employment has not been a fair or effective stepping-stone to integration in the case of visible minority immigrants. Our research indicates that a strict labour market definition of success fails to capture the expectations and real life goals of new immigrants.
\end{abstract}

Key Words: immigration, professional immigrants, workforce, integration, Manitoba

\title{
Introduction
}

Internationally educated and trained persons, professional immigrants, and skilled workers are important to the health and growth of both Canada's labour market and to global competitiveness. Historically and currently, the Government of Canada has viewed immigration as a priority by welcoming new immigrant populations. Human Resources and Skills Development Canada (HRSDC) and the Policy Roundtable Mobilizing Professionals and Trades (PROMPT) are in agreement that without immigration there will be little growth in the Canadian labour force. However, immigration and settlement processes complex and contradictory, and must be understood as more than a two-way exchange. In contrast to the claim that immigration policy recognizes the economic contribution made by immigrants to Canada, McQuillan (2013) points out that temporary foreign worker programs are being used to fill low-skilled, low-paying jobs that are not made attractive to Canadian workers. It is against this backdrop of seemingly conflicting immigration policy that potential immigrants weigh the personal costs and benefits of making a move and of making a personal sacrifice for their children.

Manitoba has weathered the contraction of the global economy better than most regions of Canada, and our preliminary research indicates that foreign educated professionals and trades people settling in that province are finding employment and experiencing a gradual increase in income. While policy-makers have laid out the welcome mat for well-educated, experienced newcomers, PROMPT identifies persistent, systemic barriers to settlement and integration. Recognition of credentials by employers is the single greatest factor explaining the inability of international qualified professionals to achieve full participation in the labour market. Galabuzi (2009) links barriers to the full use of one's skills with frustration, a sense of inequality and injustice, isolation 
and alienation, and ultimately a deterioration in mental and physical health. Manitoba has not yet witnessed the tensions that have been evident in larger urban centres, but the recent centralization of immigration and settlement programs may have a significant impact on the Manitoba success story that has been praised by employers and imitated in other provinces.

Our ongoing study emerges from three observations that frame the research and this initial paper. First, over $70 \%$ of immigrants admitted to Manitoba in 2011 were selected through the Provincial Nominee Program (Manitoba Labour and Immigration 2012), yet in many cases new immigrant labour market participation has been restricted to general labour and entrylevel employment. Second, the capability of the labour market to act as an integrating force continues to decline. The settlement fund requirement leads to a gap between demand and supply in the labour market by preferring those who can afford to emigrate over those with the specific skills that will contribute to the workforce. Our third observation is that employment, as a means of integration, has not been fair to immigrant visible minorities, and increasing numbers of temporary workers entering the labour market must compete with more educated immigrants who use entry level jobs as a stepping stone.

Our research aims to describe the integration process from the perspective of professionals and trades people who have been clients of Success Skills Centre over the past 25 years, with a view to improving programs that support integration. Based on a quantitative survey supplemented by qualitative contributions, this paper describes key aspects of the immigration experience and begins to identify factors that assist professional immigrants and skilled workers in making a successful integration into the Canadian workforce and society. We employ two definitions of success and identify factors that may have contributed to past successes. Participants in the survey have also pinpointed continuing obstacles to integration.

\section{Background to the Study}

Small- and medium-sized enterprises in both the manufacturing and exporting sectors have experienced shortages of skilled labour and these gaps in labour supply are considered the most significant barrier to economic expansion in Canada (CME 2001; Alboim 2002; Bruce 2001; Lochhead and MacKenzie 2005). An aging population and low fertility rates make Canadian demographics a contributing factor to a significant contraction in the size of the labour force. Immigration accounted for two-thirds (69.3\%) of Canada's population growth between 2001 and 2006, and immigrants comprise 19.8\% of the total population (Chui, Tran, and Maheux 2012). Human Resources and Skills Development Canada's (2011) conservative estimate is that immigrants comprise almost $65 \%$ of new labour force growth.

Research documenting immigrants' struggles to integrate into the Canadian labour market tend to focus mainly on Montreal, Toronto, and Vancouver (Alboim 2002; Bourgeault 2007; Elabor-Idemudia 2000; Knowles 1992, 2000; Krahn et al. 2000; McDae 1988; von Zweck and Burnett 2006). 
Other studies have addressed only particular programs, such as the Provincial Nominee Program (PNP) in Manitoba, or foreign-trained professionals in small Ontario communities (Carter 2009; Girard and Bauder 2005; Mukkath and Jaffray 2006; Smart n.d.). Bauder (2012) called for analysis of Canadian immigration and settlement policies in light of the "push and pull" factors emerging within the global context of international migration flows.

In Manitoba, the focus has been on the Provincial Nominee Program (PNP). Manitoba relies heavily on immigrants to meet its economic needs. In 2011, Manitoba's PNP accounted for $32.1 \%$ of the immigrants coming to Canada. In 2011, $82.4 \%$ or 13,151 people immigrated to Manitoba under the economic class and, of that number, $77.3 \%$ or 12,342 principal applicants and dependents came under the PNP (Manitoba Labour and Immigration 2012). When evaluating the earnings and retention rates of nominees across Canada, Pandey and Townsend (2011) found that nominees had higher earnings than federal economic class immigrants, and that Manitoba nominees were most likely to remain in their chosen province. Evaluations in Manitoba by Carter and others concluded that the PNP has been successful in attracting and retaining immigrants (Pandey and Townsend 2011; Carter 2009; Carter, Pandey, and Townsend 2010).

At the 10-year point in the PNP, Carter (2009) concludes the level of satisfaction among principal applicants and their spouses was quite high. The resettlement and integration experience was positive in terms of pre-arrival information and processing of applications, and the majority in the sample had found permanent employment. Typical applicants and their spouses were well educated and many pursued additional training and education opportunities, including language training. Housing did not appear to be a significant barrier to integration. Support services were positively assessed and many identified family and friends as important sources of support. The overall experience was seen to have exceeded expectations. However, Carter (2009) also flagged problems faced by some of the PNP newcomers, who received misleading information when it came to credentialing and recognition of experience outside Canada; experienced discrimination and racism; were unable to get work in their field of expertise; found education and training programs expensive and difficult to access; faced crowding in accommodations, both as renters and homeowners; were dissatisfied with the schools system in terms of poor work habits of their children and lack of cultural content; and found a lack of safely in the inner city. Adjustment for many was a struggle that was exacerbated by language, isolation, the climate, and lack of familiar foods. However, these problems were not identified by a significant proportion of the sample, and generally PNP newcomers feel positive about their decision to immigrate to Manitoba.

Though Carter (2009) identifies Manitoba's wider assortment of options as a source of flexibility and a best practice approach that allowed the province to shift a person's route in the program to meet their specific situation, the wage gap for recent immigrants has widened considerably. In 1980, recent immigrant men and women earned 85 cents for each dollar earned by Canadian-born men, but by 2005 this ratio had dropped to 63 cents. The corresponding numbers for recent immigrant women were 85 
cents and 56 cents respectively. These gaps widened even though educational attainment of recent immigrant earners rose much faster than that of their Canadian-born counterparts during this period (Statistics Canada 2006).

According to Galabuzi (2006), the growth of informal, peripheral, and non-standardized work conditions has exacerbated racial tensions and discrimination and in major centres such as Montreal, Toronto, and Vancouver (10-12). He points out that Canadian Federal Immigration Policy continues to reflect the historical image of Canada as a white-settler country modeled on British society. Globalization has been accompanied by an expanding range of economic policy shifts and changes in attitudes toward immigration, but in Europe and North America "the term immigrant has been redefined to refer to non-Whites" (Galabuzi, 2006: 83).

According to Armine Yalnyzian (Centre for Social Justice), the marketbased approach to dealing with racial inequality has failed (as cited in Galabuzi 2006). Racial segregation in the labour market leads to social outcomes such as differential access to housing, neighbourhood selection, contact with the criminal justice system, health risks, and diminished political participation (Galabuzi 2006). This segregation also leads to social exclusion, a term which encompasses a full range of "integration failures" when it is applied to new immigrants. Widespread segregation is particularly evident in the high numbers of new immigrants who can only find employment characterized by precarious wage relations.

\section{Research Methodology}

Our 2010-2011 project surveyed 100 participants (59 men, 39 women, and 2 unidentified) who provided data on their experiences as professional and skilled immigrants in Manitoba (see Table 1). The participants were identified through the intake questionnaires from Success Skills Centre, a Winnipeg agency offering employment assistance services to immigrant professionals and skilled workers. The Centre's intake data covers a period of 20 years (1989-2009) during which government policies have repeatedly redefined the characteristics of professionals who have journeyed to Canada. The response rate to the survey was $30 \%$, reflecting the positive experience and level of appreciation for the support for the support provided by Success Skills Centre.

The initial study discussed in this paper is part of a larger project that will include a multi-level analysis of the experiences and contributions of immigrants to Canada's economy, society, and culture. Conducting comprehensive and multi-phased research on immigrant professionals and trades people requires a mixed-methods approach. Quantitative and qualitative research methodologies will be used to obtain the rich information needed to fully understand immigrant workers' experience in Manitoba. Research will adopt an interdisciplinary lens to identify the challenges and opportunities that immigrants have experienced in Canada over the past 25 years, helping to address the complex topic of how professional immigrants and skilled workers' can successfully integrate into Canadian society. 
Table 1: Research Participants by Occupation

\begin{tabular}{|l|c|l|c|}
\hline Occupation & Number & Occupation & Number \\
\hline Accountant & 14 & $\begin{array}{l}\text { Human Resource } \\
\text { Personnel }\end{array}$ & 3 \\
\hline Administrator/Manager & 14 & Lawyer & 1 \\
\hline $\begin{array}{l}\text { Agricultural } \\
\text { Researcher/Specialist }\end{array}$ & 3 & Librarian & 3 \\
\hline Architect & 1 & $\begin{array}{l}\text { Quality Control Fishery } \\
\text { Personnel }\end{array}$ & 1 \\
\hline Banker & 1 & Researcher & 2 \\
\hline Business Analyst/Personnel & 3 & Sales Personnel & 1 \\
\hline Chemist & 2 & Social Worker/Pharmacist & 1 \\
\hline $\begin{array}{l}\text { Computer } \\
\text { Technologist/Software }\end{array}$ & 2 & Teacher & 3 \\
\hline Developer & 8 & University Instructor & 7 \\
\hline Doctor (Medical) & 1 & Unidentified & 1 \\
\hline Economist & 1 & & 100 \\
\hline Engineer & 26 & & TOTAL: \\
\hline $\begin{array}{l}\text { Environmental Health \& } \\
\text { Safety Personnel }\end{array}$ & 1 & & \\
\hline
\end{tabular}

Our survey of professional immigrants and skilled workers provided important data from their unique perspectives and experiences. The 100 surveys completed during the project have provided information from immigrant professionals in different disciplines and occupations over the past 25 years. This information has been transferred to a database system and organized into various themes, categories, and topics.

In studying immigrant cultures and groups involved in immigration issues, it is important for researchers to be conscious of situational and structural contexts (Strauss 1993). "Qualitative inquiry has been promoted as having intrinsic political and ethical value, in giving voice to marginalized and otherwise muted groups and/or in challenging the powerful" (Hammersley and Atkinson 2007, x). A multi-method approach incorporating ethnography, narrative, and in-depth interviews will be used in the next stage of our study (Hammersley and Atkinson 2007; Lieblich, Tuval-Mashiach, and Zilber 1998; Robben and Sluka 2007).

\section{Preliminary Analysis and Discussion Based on Quantitative Survey}

There are numerous definitions of 'success' found in the literature that analyses the employment, settlement, and integration experience of new immigrants in Canadian society and in the Canadian labour market.

\section{Immigration Success and Contextual Factors}

The success of immigrants in Canada, defined in terms of employment rates and earnings relative to the native-born population, has been in decline for 
some time. According to Reitz (2007), success is "related only partly to changes in the individual characteristics of immigrants; [the research] point also to the significance of contextual factors and changing processes within labour markets" (37). Reitz (2007) identifies some of these contextual factors that have contributed to a downward trend in immigrant employment success:

1. A general decline in employment opportunities for all new labour market entrants, which amplifies the decline for immigrants;

2. A shift in the origins of immigrants to new regions, with possible implications for human capital and labour market discrimination;

3. Rising levels of education for the native-born workforce;

4. Low returns to education for immigrants, which places them at an increasing disadvantage as the overall emphasis on education increases;

5. A decline in the recognition of foreign labour market experience for immigrants;

6. Changes in the organization of the labour market, including changes in occupational structure, human resource practices, and the shift to the "knowledge economy"; and

7. An overall increase in labour market inequality.

Reitz (2007) advocates a broader range of determinants that should be considered when describing immigrant employment success. The studies to date have concentrated on a limited range of variables available in census data, with little consideration given to labour market processes for the assessment of immigrant skills or the impact of possible changes in social capital on immigrant success (Reitz 2007).

\section{Employment Success According to a Manitoba Employer}

Economic, cultural, and societal factors have a great impact on an immigrant's perception of successful integration in Canada. As such, Art DeFehr (2011), President and CEO of Palliser Furniture, has been involved in both the development of the PNP in Manitoba and wider discussions of global migration issues. Based on his experience as an employer and policy advisor, he explains the success of Manitoba's immigration system in terms of the following factors:

1. The PNP places a high value on skills;

2. Genuine jobs have been offered to principle applicants;

3. Applications benefit from links to communities, families, ethnic, or religious groups;

4. Within the PNP vocabulary, the assessment of "likely to succeed" is frequently used to describe Manitoba's new immigrants based on factors such as having a history of regular employment in own country, a stable family, skills in demand, and a welcoming community;

5. The Manitoba PNP has been directed by the Provincial Government with significant support from the business community (CEOs of local companies); 
6. The proportion of immigrants who settled in rural Manitoba matches the existing distribution of population;

7. The rate of home ownership after 3-5 years among nominees was greater than in the local population; and

8. A majority of applicants could communicate in English after 5 years.

DeFehr (2011) points to several indicators of the PNP's success: no nominees have been on welfare, the PNP system has been imitated by other provinces, and the province has set new goals for immigration in Manitoba that are $50 \%$ higher, doubling the national growth rate.

\section{Working Definitions of Success}

In our analysis of the 100 completed surveys, we have employed two common definitions of success that emerged from the data:

Labour Market Definition. When reviewing the labour market literature for a definition of successful immigration, three common criteria are prominent: 1) whether the immigrant was able to obtain full-time employment, 2 ) whether he or she was able to earn a weekly average income of $\$ 600$ or higher, a rate similar to the earnings of native-born Canadians, and 3 ) whether employment is directly related to education and training so that the immigrant's human resources are fully employed.

Personal Definition. Determination of immigration success can be based on a more personal definition. According to this approach, success depends on whether an immigrant's expectations in immigration and integration have been met, which can be attributed to employment, family, or communitybased criteria. This could include measuring an immigrant's satisfaction with his or her employment, his or her sense of feeling at home in the host country, and his or her belief that the hopes of the next generation are likely to be fulfilled.

\section{Analysis \& Discussion}

Under the labour market definition, our success criteria are comprised of fulltime employment, weekly earnings in excess of $\$ 600$, and employment directly related to education and/or training. Weekly earnings of $\$ 600$ are based on Statistics Canada's Market-based Measure threshold for two adults and two children for 2010. This level of earnings provides a modest, basic standard of living in Manitoba (Statistics Canada 2013). The number of participants meeting all three criteria is 25 (see Table 2).

The most successful occupations in our survey of 100 professionals and trades people are: Engineers (11), Accountants (2), Bankers/Financial Analysts (2), Chemists (4), University Instructors (2), and (1) for each of Business, Manager, Researcher, and Social Worker. Sixteen men, 7 women, and 2 unidentified genders were successful under these criteria. It is not surprising that immigrant professionals and trades people in these highly valued professions have found employment. One would expect that these 
occupations attract people with high-level organizational and management skills.

Accountants were recently incorporated into the bridge-to-work program at the Asper School of Business at the University of Manitoba, adding another explanation for the success of certain professionals. Similar programs are already available for foreign-trained doctors, dentists, engineers, teachers, and agrologists. This program is a response to the failure of immigrants to find work in their fields because they did not meet Canadian standards (Owen 2010). Eight occupations have been fast-tracked in Manitoba for professional credentials. Initially, bridge programs were established for nurses, architects, and engineers. The next group included financial auditors and accountants, medical laboratory technologists, occupational therapists, pharmacists, and physiotherapists. Finally, physicians, dentists, engineering technicians, licensed practical nurses, medical radiation technologists, and teachers for kindergarten to Grade 12 were provided with a bridging program (Martin 2009).

From our current data, the most likely profile of a successful immigrant would be as follows: (1) male; (2) married; (3) from the Philippines; (4) came under PNP; (5) fluent in English; (6) has a BA; (7) has taken additional training; and (8) has over 10 years of experience (see Table 2). These are the most common characteristics of those who succeeded in our sample, though a more in-depth study is needed to determine significant factors and causal relationships leading to success.

We subsequently applied our personal definition of immigrants' success based on participants' response to the following question: "In relation to your prior information about Manitoba and your own expectations in finding a job in the province, how successful do you think you have been in getting a job, and settling yourself in the Canadian environment?" The results show that 60 participants felt they had been successful. This number is about 2.5 times as high as the result from the labour market definition, which determined that only 25 immigrants were successful in their immigration experience (see Table 3).

In the opinion of our respondents, clearly there are factors other than employment success that contribute to 'successful immigration' and 'settlement.' In this case, the most successful occupations in our survey of 100 professionals and trades people are: Engineers (17), Accountants (7); Administrator (3); Agriculturalists (3); Architects (2); Bankers/Financial Analysts (2); Business (2); Chemists (2); Doctors (2); Environmental Safety and Health (3); Librarians (3); Teachers (3); University Instructors (6); and (1) for each of Computers/Information Technologist; Economist; Human Resource Manager, Sales/Retailer, and Social Worker. Thirty men and thirty women were successful according to their own personal evaluation criteria. As was the case in our labour market definition, engineers are most successful under the personal definition. In addition, equal numbers of men and women are successful, and more participants who work in the social science fields consider themselves successful under the personal criterion of success. 
Table 2: Survey Participants Who Succeeded: Labour Market Definition of Success

\begin{tabular}{|c|c|c|}
\hline Characteristics & \multicolumn{2}{|c|}{ Percentage (of 25 who succeeded) } \\
\hline 1. Gender (2 gave no answer) & $\begin{array}{c}\text { Male } \\
64\end{array}$ & $\begin{array}{c}\text { Female } \\
28\end{array}$ \\
\hline $\begin{array}{l}\text { 2. Marital Status } \\
\text { ( } 1 \text { gave no answer) }\end{array}$ & $\begin{array}{l}\text { Married } \\
88 \\
\end{array}$ & $\begin{array}{c}\text { Single/Other } \\
8 \\
\end{array}$ \\
\hline \multicolumn{3}{|l|}{ 3. Country of Origin } \\
\hline Philippines & \multicolumn{2}{|c|}{28} \\
\hline African Nations & \multicolumn{2}{|c|}{24} \\
\hline India/Pakistan & \multicolumn{2}{|c|}{16} \\
\hline South/Central America & \multicolumn{2}{|c|}{16} \\
\hline Ukraine/Russian/E. Europe & \multicolumn{2}{|c|}{8} \\
\hline China/Hong Kong & \multicolumn{2}{|c|}{8} \\
\hline 4. Time in Canada & $\begin{array}{c}3 \text { or }<3 \text { years } \\
48\end{array}$ & $\begin{array}{c}>3 \text { years } \\
52\end{array}$ \\
\hline $\begin{array}{l}\text { 5. Arrived under PNP } \\
\text { (1 gave no answer) }\end{array}$ & $\begin{array}{l}\text { Yes } \\
56\end{array}$ & $\begin{array}{l}\text { No } \\
40\end{array}$ \\
\hline 6. English Proficiency & $\begin{array}{c}\text { Fluency } \\
60\end{array}$ & $\begin{array}{l}\text { Less Fluent } \\
40\end{array}$ \\
\hline \multicolumn{3}{|l|}{ 7. Education } \\
\hline PhD/Civil Engineering & \multicolumn{2}{|c|}{16} \\
\hline Master's Degree & \multicolumn{2}{|c|}{32} \\
\hline $\mathrm{BA}$ & \multicolumn{2}{|c|}{40} \\
\hline Diploma/Technical Certificate & \multicolumn{2}{|c|}{12} \\
\hline 8. Training in Canada & $\begin{array}{l}\text { Training } \\
72\end{array}$ & $\begin{array}{c}\text { No Training } \\
28\end{array}$ \\
\hline 9. Years of Experience & $\begin{array}{c}10 \text { or }<10 \text { years } \\
36\end{array}$ & $\begin{array}{c}>10 \text { years } \\
64\end{array}$ \\
\hline $\begin{array}{l}\text { 10. Credentials } \\
\text { (15/25 sought credentialing) } \\
\text { (38\% of the } 25 \text { did not seek } \\
\text { credentialing) }\end{array}$ & $\begin{array}{c}\text { Sought/Received } \\
24\end{array}$ & $\begin{array}{l}\text { Sought/ Not } \\
\text { Received } \\
38\end{array}$ \\
\hline 11. Family Members in Canada & $\begin{array}{l}\text { Yes } \\
52\end{array}$ & $\begin{array}{l}\text { No } \\
48\end{array}$ \\
\hline
\end{tabular}

From our current data, the most likely profile of a successful immigrant would be as follows: (1) male or female; (2) married; (3) from the Philippines; (4) less than 4 years in Canada; (5) arrived under the PNP; (6) has a Bachelor's of Arts degree; (7) has taken additional training in Canada; (8) has over 10 years experience; and (9) has family in Canada (see Table 3). These are the most common characteristics of those who succeeded according to the personal definition of success. A more in-depth study is needed to determine significant factors and causal relationships leading to success.

Our two profiles are slightly different: both men and women were equally successful under the personal definition of success, and family seems to have been a more important support for that larger group of successful immigrants. 
Table 3: Survey Participants Who Succeeded: Personal Definition of Success

\begin{tabular}{|c|c|c|}
\hline Characteristics & \multicolumn{2}{|c|}{ Percentage (of 60 who succeeded) } \\
\hline 1. Gender & $\begin{array}{l}\text { Male } \\
50\end{array}$ & $\begin{array}{l}\text { Female } \\
50\end{array}$ \\
\hline $\begin{array}{l}\text { 2. Marital Status } \\
\text { (1 gave no answer) }\end{array}$ & $\begin{array}{l}\text { Married } \\
\quad 77\end{array}$ & $\begin{array}{l}\text { Single/Other } \\
22\end{array}$ \\
\hline \multicolumn{3}{|l|}{ 3. Country of Origin } \\
\hline Philippines & \multirow{2}{*}{\multicolumn{2}{|c|}{35}} \\
\hline African Nations & & \\
\hline India/Pakistan & \multicolumn{2}{|c|}{$\frac{20}{15}$} \\
\hline South/Central America & \multicolumn{2}{|c|}{9} \\
\hline Ukraine/Russia/E. Europe & \multicolumn{2}{|c|}{15} \\
\hline China/Hong Kong & \multicolumn{2}{|c|}{3} \\
\hline W. Europe & \multicolumn{2}{|c|}{1.5} \\
\hline Middle East & \multicolumn{2}{|c|}{1.5} \\
\hline 4. Time in Canada & $\begin{array}{c}3 \text { or }<3 \text { years } \\
58\end{array}$ & $\begin{array}{c}>3 \text { years } \\
42\end{array}$ \\
\hline $\begin{array}{l}\text { 5. Arrived under PNP } \\
\text { ( } 5 \text { gave no answer) }\end{array}$ & $\begin{array}{l}\text { Yes } \\
52\end{array}$ & $\begin{array}{l}\text { No } \\
40\end{array}$ \\
\hline 6. English Proficiency & $\begin{array}{l}\text { Fluency } \\
53\end{array}$ & $\begin{array}{l}\text { Less Fluent } \\
\quad 47\end{array}$ \\
\hline \multicolumn{3}{|l|}{ 7. Education } \\
\hline PhD/Civil Engineering & \multicolumn{2}{|c|}{8} \\
\hline Master's Degree & \multicolumn{2}{|c|}{32} \\
\hline BA & & \\
\hline Diploma/Technical Certificate & \multicolumn{2}{|c|}{$\begin{array}{l}47 \\
13\end{array}$} \\
\hline $\begin{array}{l}\text { 8. Training in Canada } \\
\text { (4 gave no answer) }\end{array}$ & $\begin{array}{l}\text { Training } \\
65\end{array}$ & $\begin{array}{l}\text { No Training } \\
28\end{array}$ \\
\hline 9. Years of Experience & $\begin{array}{c}10 \text { or }<10 \text { years } \\
40\end{array}$ & $\begin{array}{l}>10 \text { years } \\
60\end{array}$ \\
\hline $\begin{array}{l}\text { 10. Credentials } \\
\text { ( } 34 / 60 \text { sought credentialing) } \\
\text { ( } 43 \% \text { of the } 60 \text { did not seek } \\
\text { credentialing) }\end{array}$ & $\begin{array}{c}\text { Sought/Received } \\
30\end{array}$ & $\begin{array}{c}\text { Sought/ Not } \\
\text { Received } \\
27\end{array}$ \\
\hline $\begin{array}{l}\text { 11. Family Members in Canada } \\
\text { ( } 2 \text { gave no answer) }\end{array}$ & $\begin{array}{l}\text { Yes } \\
67\end{array}$ & $\begin{array}{l}\text { No } \\
30\end{array}$ \\
\hline
\end{tabular}

Obstacles Encountered by Immigrant Professionals Seeking Employment and Resettlement

We asked the 100 participants in our study if they had encountered any of the 10 most frequently cited barriers to employment for new immigrants such as difficulty with English skills, racial prejudice, employers not recognizing credentials, a need for "Canadian Experience," difficulty finding options for employment, and difficulties in integrating into the workplace 
setting (see Table 4). The wider conditions that affected immigrants' job searches included legal, health, financial, and housing issues that resulted in time and energy costs that produced stress and uncertainty. At a time when newly arrived professionals and workers would want to have structure and support for their efforts, they may find that their situation may or may not be conducive to obtaining the position that matches their qualifications and experience.

Table 4: Obstacles to Employment and Resettlement for Men (M) and Women (F)

\begin{tabular}{|l|r|r|r|r|r|r|}
\hline Obstacle $^{*}$ & \multicolumn{2}{|c|}{ Not at all } & \multicolumn{2}{|c|}{ Slightly } & \multicolumn{2}{c|}{ Seriously } \\
\hline & $\% \mathrm{M}$ & $\% \mathrm{~F}$ & $\% \mathrm{M}$ & $\% \mathrm{~F}$ & $\% \mathrm{M}$ & $\% \mathrm{~F}$ \\
\hline Difficulty with English & 41.3 & 60.0 & 32.8 & 12.8 & 8.6 & 18.0 \\
\hline Racial Prejudice/Discrimination & 43.1 & 51.3 & 27.6 & 28.2 & 12.1 & 7.7 \\
\hline Lack Recognition of Credentials & 20.7 & 30.8 & 24.1 & 30.8 & 43.1 & 28.2 \\
\hline Lack of Canadian Experience & 8.6 & 10.3 & 27.6 & 43.6 & 50.0 & 38.5 \\
\hline Difficult Finding Employment & 6.9 & 15.4 & 20.7 & 33.3 & 58.6 & 51.3 \\
\hline Work Integration Difficult** & 27.5 & 48.7 & 43.1 & 33.3 & 19.0 & 15.4 \\
\hline Legal Concerns ** & 77.6 & 97.4 & 5.2 & 0 & 3.4 & 2.6 \\
\hline Health Concerns & 41.4 & 61.5 & 39.7 & 28.2 & 3.4 & 10.3 \\
\hline Financial concerns & 15.5 & 38.5 & 50.0 & 35.9 & 20.7 & 18.0 \\
\hline Housing Issues & 22.4 & 51.3 & 41.3 & 30.8 & 17.2 & 10.3 \\
\hline Other & 8.6 & 20.5 & 12.1 & 7.7 & 3.4 & 28.2 \\
\hline Notes: & & & & & &
\end{tabular}

Notes:

*Each row represents responses for $100 \%$ of respondents

** Some people found workplace integration difficult - about $10 \%$ did not answer this question because they had not yet had a chance to work.

${ }^{* * *}$ It is possible that legal concerns might be underreported.

The following obstacles for professional immigrants can be highlighted based on Table 4:

\section{Serious Concerns for Men and Women}

- Almost two-thirds of the men and half of the women in our sample had significant difficulties finding employment. Half of the men and forty percent of the women cited lack of Canadian experience as a serious obstacle to employment.

- Men found that employers did not recognize their credentials more often than women did $-43 \%$ of men had serious problems in this regard. Women had a mixed experience when it came to being given credit for their professional accomplishments outside of Canada - they were equally likely to have serious, slight, or no problems with credential recognition. 
2. Slight Concerns for Men and Women:

- While difficulty with English was a relatively slight concern for $1 / 3$ of men, it was not at all a concern for $60 \%$ of women and $41 \%$ of men in the sample.

- Racial prejudice was likewise considered a slight concern for almost $1 / 3$ of the men and women, but it was not at all a concern for $43 \%$ of men and $51 \%$ of women.

- Legal issues were a very low concern of the men and women in our sample. However, it is likely that legal concerns would be underreported when respondents considered themselves vulnerable.

- More men than women had slight health concerns, with $61 \%$ of women rating health as not a barrier at all.

3. Continuing Concerns Regarding Prejudice, Health services, and Housing

- Close to $30 \%$ of men and women had a slight concern with prejudice and discrimination.

- Slight health concerns were identified by $40 \%$ of men and $28 \%$ of women.

- Slight housing issues were identified by $41 \%$ of men and $31 \%$ of women.

A question that arises from this analysis is whether certain barriers in fact might be interpreted as "code" for actual racism and discrimination. Our study did not identify high ratings of prejudice or discrimination as a barrier to employment relative to other barriers. However, since close to $30 \%$ of men and women in our sample identified racial prejudice as even a "slight" problem, discrimination is still a concern. Does requiring a "Canadian experience" mean that the workplace is racialized? Comments accompanying the rating of obstacles in our questionnaire are compiled in Table 5, and these provide further insight into the possible racialized aspects of the immigration experience.

Table 5: Comments on Obstacles to Integration from Survey Participants

\begin{tabular}{|l|l|}
\hline Obstacle & Comments \\
\hline Difficulty with English & $\begin{array}{l}\text { Learning the idiomatic expressions used here } \\
\text { and the local terms is not easy. } \\
\text { They don't understand my accent - my field is } \\
\text { administration. }\end{array}$ \\
\hline $\begin{array}{l}\text { Racial } \\
\text { Prejudice/Discrimination }\end{array}$ & $\begin{array}{l}\text { My partner who was originally from South } \\
\text { America was treated as if she was First } \\
\text { Nations. } \\
\text { Racial prejudice exists - especially at the job } \\
\text { (job: occupation administration; source country: } \\
\text { Hong Kong,). }\end{array}$ \\
\hline $\begin{array}{l}\text { Lack Recognition of } \\
\text { Credentials }\end{array}$ & $\begin{array}{l}\text { Irom the UK and had practiced for 10 years. } \\
\text { I was given subjects credit recognition but I am } \\
\text { required to re-enroll in the university to be able }\end{array}$ \\
\hline
\end{tabular}




\begin{tabular}{|c|c|}
\hline & $\begin{array}{l}\text { to get a CleA designation. Even I have taken } \\
6 \text { AP subjects in the ITAP Program for no clear } \\
\text { justification. It's maybe the school where I come } \\
\text { from (occupation accounting). }\end{array}$ \\
\hline $\begin{array}{l}\text { Lack of Canadian } \\
\text { Experience }\end{array}$ & $\begin{array}{l}\text { Lack of Canadian experience meant I had no } \\
\text { interviews. All jobs require Canadian } \\
\text { experience (source country: Nigeria). } \\
\text { It's difficult to find employment, since most of } \\
\text { the employers are looking for applicants with } \\
\text { Canadian experience. I applied for many but no } \\
\text { reply. }\end{array}$ \\
\hline $\begin{array}{l}\text { Difficult Finding } \\
\text { Employment }\end{array}$ & $\begin{array}{l}\text { If you go for a survival job, you are } \\
\text { overqualified, and if you go for jobs in my field, } \\
\text { they are limited. }\end{array}$ \\
\hline Work Integration Difficult & $\begin{array}{l}\text { Personal integration is a problem because it's a } \\
\text { new environment and needs some getting used } \\
\text { to. } \\
\text { For me, the most concern that I really had was } \\
\text { integrating into the workplace culture. It took me } \\
\text { months to understand the ways of a Canadian } \\
\text { workplace. }\end{array}$ \\
\hline Legal Concerns & $\begin{array}{l}\text { Legal issue of getting visa for parents was a } \\
\text { problem }\end{array}$ \\
\hline Health Concerns & $\begin{array}{l}\text { Finding a family doctor is really hard, especially } \\
\text { for women. } \\
\text { It's difficult to buy medicine especially for us } \\
\text { unemployed. } \\
\text { Doctors in walk-in clinics hardly give enough } \\
\text { time to examine you. Emergency service at the } \\
\text { hospital made my husband wait for } 5 \text { hours! } \\
\text { Medical attention is extremely slow in this } \\
\text { country. It's the worst l've ever encountered. }\end{array}$ \\
\hline Financial concerns & $\begin{array}{l}\text { Daycare, apartment rental - both took us long } \\
\text { to find because of the long waiting list and } \\
\text { daycare can be expensive too since I have } 2 \\
\text { kids still in daycare. } \\
\text { There should be some way to make exceptions } \\
\text { (within reason, of course) for new immigrants } \\
\text { on credit ratings. } \\
\text { I did not have enough credit information to buy } \\
\text { a car, or even a cell phone. }\end{array}$ \\
\hline Housing Issues & $\begin{array}{l}\text { There does not seem to be much social } \\
\text { housing. } \\
\text { Without income it is hard to find a house. } \\
\text { Buying a home is very expensive especially } \\
\text { with the } 5 \% \text { minimum down payments and } \\
\text { housing cost is rocketing }\end{array}$ \\
\hline
\end{tabular}




\section{Immigrant Narratives on Obstacles to Employment}

There are a number of themes shared by other studies of newcomer experiences of workplace and community integration, and the stories related by our survey participants. In particular, commonalities included language barriers, cultural differences that make workplace integration difficult, and unmet expectations. One story in our study featured successful workplace integration for the wife but not her husband. Both were successful doctors in their home country, where they practiced medicine for 15 years. Upon arriving in Canada, they wrote medical exams to assess their knowledge and skills. The wife passed the exams and was able to spend a short time in medical school in order to obtain her medical license. The husband, however, did not pass. When the wife opened her own practice, her husband ended up providing clerical support in the office. Like so many other newcomers who were considered qualified in their home country, the husband now works in a position below the qualifications he received. It is beyond the scope of this paper to discuss the intrapersonal and interpersonal conflicts that may arise from this mismatch in post-arrival qualifications and employment, particularly in the context of a domestic partnership, but in this case the situation resulted in serious family tensions.

Another story involves two very experienced seamstresses who immigrated to Canada from Asia and were quickly hired at a garment factory. The employer, knowing that they were immigrants, paid them a lower wage than Canadian-born workers. There were also times when the women would not be given their pay cheques. The women needed their jobs in order to provide for their families, so they remained quiet about their inequitable working situation.

These stories illustrate forms of racial discrimination in employment identified by Galabuzi (2006):

1. Differential treatment in recruitment, hiring, and promotions;

2. Extensive reliance on non-transparent forms of recruitment (e.g., word of mouth);

3. Differential valuation or effective devaluation of internationally obtained credentials;

4. Demands for Canadian experience; and

5. Use of immigrant status as a proxy for lower quality of human capital.

Our study indicates that, although there are looming shortages in many professions as the Canadian labour force ages, newcomer professionals and skilled tradespeople encounter some serious obstacles. Highlighted in our statistics are those whose credentials are not recognized, the frustrating claim that Canadian experience is lacking in newly arrived workers, and the range of factors that make finding employment in an unfamiliar labour market very difficult, even for those who have been screened and achieve high scores prior to entry into Canada.

Meridji (2009) describes the Manitoba context as one that has been conducive to settlement and retention. He distinguishes three types of networks that have been significant in the integration process in Winnipeg: 1) 
social and family networks, 2) ethnic networks, and 3) neighbourhood support networks. These networks provide multifaceted support to recent immigrants, "facilitating formation of ethnic economies and infrastructure catering to immigrants' cultural and fundamental needs" (n.p.). Ethnic networks among spatially concentrated populations are important, serving to familiarize recent immigrants with "the labour market, the welfare state, and civil society." The Neighbourhood Immigrant Settlement Workers Network is led by dedicated staff and volunteers in the program, who treat immigrant clients as subjects rather than objects, and are guided by the understanding that if they match their services with the real-life experiences of the newcomer populations, they are able to "breathe new life into newcomer's families" (Neighbourhood Immigrant Settlement Workers 2013). These organizations provide necessary information leading to more successful integration into the labour market, especially for visible minority immigrants.

\section{Preliminary Conclusions and Future Research}

According to our labour market definition of success, only one-quarter of the respondents in our study were successful in their employment and integration into Canadian society. In contrast, when asked to evaluate their employment and integration experience in relation to initial expectations, the success rate more than doubled to $60 \%$. Despite the fact that immigrants are advised and convinced that their first priority is finding work, they also value other social and family benefits of immigration.

Many of our respondents referenced the Success Skills Centre and other provincial support programs as important contributors to their success, and a majority had availed themselves of training programs to improve their English. Our data shows the importance of such programs and services in helping new immigrants to successfully integrate into the workforce.

Respondents expanded on concerns about settling in Manitoba, highlighting expensive childcare and an under-resourced health system as sources of considerable frustration. The most prevalent obstacles to successful resettlement were not surprising since they have been highlighted in existing quantitative and qualitative research. Our research reconfirms that immigration is hampered by the lack of recognition of credentials, lack of Canadian work experience, difficulties in finding work in one's field, and a racialized labour market. From the participants' survey comments, we observe that discrimination may be a factor embedded in other obstacles such as a demand for Canadian work experience.

According to various research, immigrants to Manitoba have benefitted from links to communities, families, ethnic, and religious groups, and initiatives that have addressed the specific needs of individuals and newcomer communities. Family networks, ethnic networks, and neighbourhood support networks are key factors in successful employment and integration. These networks need to be further researched and supported in the resettlement process.

Canada's immigration policy has recently been subject to major changes. In their report for the Maytree Foundation, "Shaping the Future," 
Alboim and Cohl (2012) discuss trends in and consequences of shifts in immigration policy. The cumulative effects of changing federal immigration policy characterize the movement towards a shortsighted, "just-in-time" market strategy. The recent federal policy emphasis on making temporary foreign workers the central vehicle for meeting short-term labour needs is seen as detrimental to existing new immigrant workers, as newcomers will not have the opportunity to access entry-level positions as they did in the past. Policymakers may be underestimating the obstacles faced by well-educated professionals in a grueling integration and settlement process, and may not recognize that entry-level jobs are often the stepping-stone to success. Manitoba's experience provides evidence that successful retention and integration of new immigrants requires a broader definition of successful settlement. The obstacles identified in our research indicate the need for public education of residents and employers, as well as the development of a consultative process that would increase dialogue on the long-term social and economic objectives and human rights issues that are central to immigration and settlement policy.

Future in-depth interviews in the second stage of our research will provide more details on strategies that work for immigrant professionals and trades people. This second stage will feature the voices of immigrants, their families, and their surrounding communities, providing a clear picture of the mutual benefits and of the "push and pull" factors in the global immigration process, adding depth and presenting the best practices of current programs in historical context.

\section{References}

Alboim, Naomi. 2011. Fulfilling the Promise: Integrating Immigrant Skills into the Canadian Economy. Caledon Institute of Social Policy 2002 [cited October 10 2011]. Available from http://www.caledoninst.or/Publications/PDF/553820134.pdf.

Alboim, Naomi, and Karen Cohl. 2012. Shaping the future: Canada's rapidly changing immigration policies: Maytree.

Bauder, Harald, ed. 2012. Immigration and Settlement: Challenges, Experiences, and Opportunities. Toronto: Canadian Scholars' Press Inc.

Bourgeault, Ivy L. . 2007. Brain Drain, Brain Gain and Brain Waste: Programs Aimed at Integrating and Retaining the Best and the Brightest in Health Care. Canadian Issues:96-99.

Bruce, D. 2001. Help Wanted: Results of CFIB Surveys on the Shortage of Qualified Labour. Toronto: Canadian Federation of Independent Business.

Carter, Tom. 2010. An Evaluation of the Manitoba Provincial Nominee Program 2009 [cited November 10 2010]. Available from http://www2.immigratemanitoba.com/asset library/en/resources/pdf/pnpmanitoba-provincial-nominee-program-tom-carter-report-2009.pdf. 
Carter, Tom, Manish Pandey, and James Townsend. 2010. The Manitoba Provincial Nominee Program: Attraction, Integration and Retention of Immigrants. Institue for Research on Public Policy:1-41.

Chui, Tina, Kelly Tran, and Helene Maheux. 2012. 2006 Census: Immigration in Canada: A Portrait of the Foreign-born Population, 2006 Census:

Findings. Statistics Canada 2012 [cited January 5 2012]. Available from http://www12.statcan.ca/census-recensement/2006/as-sa/97-557/indexeng.cfm.

CME. 2001. Canadian Manufacturers and Exporters. Management Issues Survey 2001-2003.

DeFehr, Arthur. 2011. Making Sense of Migration. Winnipeg.

Elabor-Idemudia, P. 2000. Challenges Confronting African Immigrant Women in the Canadian Workforce, edited by Calliste and G. Dei.

Galabuzi, Grace-Edward. 2006. Canada's Economic Apartheid: The Social Exclusion of Racialized Groups in the New Century. Toronto: Canadian Scholars' Press Inc.

_ 2009. Social Exclusion. In Social Determinants of Health, edited by D. Raphael. Toronto: Canadian Scholars' Press Inc.

Girard, E., and H Bauder. 2010. Barriers Blocking the Integration of Foreign Trained Immigrant Professionals: Implications for Smaller Communities in Ontario 2005 [cited November 14 2010]. Available from http://www.uoguelph.ca/geography/research/ffw/papers/immigrant credentials.pdf.

Hammersley, Martyn, and Paul Atkinson. 2007. Ethnography. 3rd ed. London: Routledge: Taylor \& Francis Group.

Human Resources and Skills Development Canada. 2011. Canadian Occupational Projection System (COPS): Government of Canada.

Knowles, V. 1992. Strangers at Our Gates: Canadian Immigration and Immigration Policy, 1540 - 1990. Toronto: Dundurn Press.

_. 2000. Forging Our Legacy: Canadian Citizenship and Immigration, 1900 - 1977. Ottawa: Citizenship and Immigration Canada.

Krahn, Harvey, Tracey Derwing, Marlene Mulder, and Lori Wilkinson. 2000. Educated and Under-Employed: Refugee Integration into the Canadian Labour Market. International Migration and Integration 1 (1):59-84.

Lieblich, A., R. Tuval-Mashiach, and T. Zilber. 1998. Narrative Research: Reading and Analysis, and Interpretation. Thousand Oaks: Sage Publications.

Lochhead, C., and P. MacKenzie. 2005. Integrating Newcomers into the Canadian Labour Market. Canadian Diversity:103-111.

Manitoba Labour and Immigration. 2012. Manitoba Immigration Facts - 2011 Statistical Report: Government of Manitoba.

Martin, Nick. 2009. Foreign workers put on fast track. Winnipeg Free Press, December 1, 2009. 
McDae, K. 1988. Barriers to Recognition of the Credentials of Immigrants in Canada. Ottawa: Institute for Research on Public Policy.

McQuillan, Kevin. 2013. All the Workers We Need: Debunking Canada's Labour-Shortage Fallacy. School of Public Policy(SPP) Research Papers 6 (16).

Mukkath, Sabin, and Don Jaffray. 2006. Report on the Immigrant Skills Workforce Integration Project: A Plan for Hamilton. Hamilton: Hamilton Community Foundation.

Neighbourhood Immigrant Settlement Workers. 2013. Neighbourhood Immigrant Settlement Workers. NISW 2013 [cited May 1, 2013 2013]. Available fromhttp://ccednet-rcdec.ca/en/node/10621.

Owen, Bruce. 2010. Governments boost training for immigrants. Winnipeg Free Press, July 17, 2010.

Pandey, Manish, and James Townsend. 2011. Provincial Nominee Programs: An Evaluation of the Earnings and Retention Rates of Nominees. Prairie Metropolis Centre Working Papers Series.

Reitz, Jeffrey G. 2007. Immigrant Employment Success in Canada, Part I: Individual and Contextual Causes. Journal of International Migration and Integration 8 (1):11-36.

Robben, Antonius C.G.M., and Jeffrey A. Sluka, eds. 2007. Ethnographic Fieldwork: An Anthropological Reader. Edited by A. C. G. M. Robben and J. A. Sluka, Ethnographic Fieldwork: An Anthropological Reader. Malden: Blackwell Publishing.

Smart, Alan. n.d. Restructuring in a North American City: Labour Markets and Political Economy in Calgary. In Globalization and Regionalism, edited by M. Rees and J. Smart. Lanham: University Press of America.

Statistics Canada. 2009. Earnings and Incomes of Canadians Over the Past Quarter Century, 2006 Consus: Data Tables, Figures, and Maps. Statistics Canads 2006 [cited October 5 2009]. Available from http://www12.statcan.gc.ca/census-recensement/2006/as-sa/97563/tables-tableaux-notes-eng.cfm.

- 2013. Table 4 Market Basket Measure Thresholds (2011-base) for Reference Family of Two Adults and Two Children by MBM Region. Government of Canada 2013 [cited March 10 2013]. Available from http://www.statcan.gc.ca/pub/75f0002m/2013002/tbl/tbl04-eng.htm.

Strauss, Anselm L. 1993. Continual Permutations of Action (Communication and Social Order). New York: Aldine De Gruyter.

von Zweck, Claudia, and Pamela Burnett. 2006. The Acculturation of Internationally Educated Health Professionals in Canada. Occupational Therapy Now 8 (3). 